\title{
Characterization of Dunaliella salina strains by flow cytometry: a new approach to select carotenoid hyperproducing strains
}

\author{
Héctor Mendoza* \\ Departamento de Biotecnología \\ División de Investigación y Desarrollo Tecnológico \\ Instituto Tecnológico de Canarias \\ Pozo Izquierdo, 35119 Sta. Lucía, Canary Islands, Spain \\ Tel: 34928727555 \\ Fax: 34928727517 \\ E-mail: hmendoza@itccanarias.org
}

Adelina de la Jara

Departamento de Biotecnología

División de Investigación y Desarrollo Tecnológico

Instituto Tecnológico de Canarias

Pozo Izquierdo, 35119 Sta. Lucía, Canary Islands, Spain

Tel: 34928727544

Fax: 34928727517

E-mail: adelajara@itccanarias.org

Karen Freijanes

Departamento de Biotecnología

División de Investigación y Desarrollo Tecnológico Instituto Tecnológico de Canarias

Pozo Izquierdo, 35119 Sta. Lucía, Canary Islands, Spain Tel: 34928727544

Fax: 34928727517

E-mail: kfreijanes@itccanarias.org

\section{Laura Carmona}

Departamento de Biotecnología

División de Investigación y Desarrollo Tecnológico

Instituto Tecnológico de Canarias

Pozo Izquierdo, 35119 Sta. Lucía, Canary Islands, Spain

Tel: 34928727544

Fax: 34928727517

E-mail: lcarmona@itccanarias.org

\section{Ana Alexandra Ramos}

Centre of Marine Sciences

Campus de Gambelas

8005-139 Faro, Portugal

Tel: 35196518375

Fax: 351299818353

E-mail: xramos@ualg.pt

\section{Vanessa de Sousa Duarte \\ Centre of Marine Sciences \\ Campus de Gambelas \\ 8005-139 Faro, Portugal \\ Tel: 35196518375 \\ Fax: 351299818353 \\ E-mail: vsousa@ualg.pt}

\section{João Carlos Serafim Varela \\ Centre of Marine Sciences \\ Campus de Gambelas \\ 8005-139 Faro, Portugal \\ Tel: 35196518375 \\ Fax: 351299818353 \\ E-mail: jvarela@ualg.pt}

Websites: http://www.itccanarias.org

http://www.ccmar.ualg.pt/institucional.htm 
Financial support: This research was partially supported by Interreg IIIB European programme, Project 159-SAL, the FCT research project OVERCAROTEN POCTI/MAR/15237/99 and the Portuguese national budget.

Keywords: carotene, carotenogenesis, Dunaliella salina, flow cytometry, Nile red.

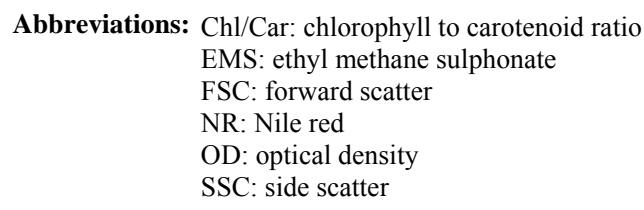

In the present work the characterization of different strains of Dunaliella salina from established cell culture collections and various isolates from solar saltworks located in the Canary Island, as well as one mutant, was carried out in order to assess the existence of intraspecific differences and to determine the potential productivity of each one. Morphological characteristics such as cellular size and cellular complexity and parameters linked to cellular physiology, such as pigment content or cellular growth rate, were determined by means of traditional techniques as well as flow cytometry. Results showed a high morphological and physiological intraspecific variability among the studied strains. Results suggest that the application of the lipidic dye Nile red allowed the development of a cytometric method faster than the traditional techniques to select carotenoid hyperproducing strains of microalgae.

Dunaliella salina is one of the few species of microalgae which can be mass cultured outdoors (García-González et al. 2003), including semi intensive systems in hypersaline lakes (Ben-Amotz, 2004). The reason for that lies in its wide halotolerance range, which allows the use of hypersaline culture medium not suitable for the growth of other organisms. Only under extreme culture conditions, such as high salinity, it is possible to minimize contamination of mass culture with opportunistic species or other organisms (Pulz, 2001).

The first pilot plant for mass culture of Dunaliella culture was established in the URSS in 1996 (Oren, 2005). Nowadays $D$. salina is one of the microalgal species more often used for mass culture due to its ability to accumulate $\beta$-carotene, a molecule which in this algae can represent up to $95 \%$ of total carotenoids (Jiménez and Pick, 1994) and has become the most commercially demanded carotenoid. The estimated market size for natural $\beta$-carotene is $10-100$ tons.year ${ }^{-1}$ and its price is higher than $750 € \cdot \mathrm{kg}^{-1}$ (Pulz, 2001). Several industrial production plants are operating in Australia, Israel, USA and China (León et al. 2003; GarcíaGonzález et al. 2005), as well as small plants which are located in other countries such as Chile or Iran (BenAmotz, 2004).
D. salina shows, however, important intraspecific variability in the $\beta$-carotene levels (Guevara et al. 2005). This feature of $D$. salina is probably closely related to its nature of extremophile which favours the natural growth of this alga in isolated environments such as solar saltworks and hypersaline lakes (González et al. 2001). Some strains achieve concentrations higher than $14 \%$ in terms of dry weight (Raja et al. 2007). Furthermore, $\beta$-carotene production in $D$. salina shows a high degree of plasticity, being possible to obtain hyperproducing mutants (Shaish et al. 1991). For these reasons the screening of natural or mutant hyperproducing strains of $D$. salina could be an optimal way to improve $\beta$-carotene production in cultures of this specie (Phadwal and Singh, 2003).

In the present work we suggest a new approach to select carotenoid hyperproducing strains of $D$. salina using flow cytometry. Compared to the traditional screening methods, flow cytometry allows processing a great amount of samples in a reduced time since this technique makes possible the analysis and isolation of microbes, vegetal or animal cells at rates of up to 1000 cells per second. However, the application of the present method had to clear two major hurdles: 1) the identification of the correct target parameters for a screening by flow cytometry of $D$. salina cells; and 2) the low fluorescence of carotenoids. Both obstacles were overcome by staining cells with Nile red (NR) (9-diethylamina-5Hbenzo[a]phenoxarine-5-one), a fluorescent dye often used in cellular biology as a cytoplasmic lipid marker (Alonzo and Mayzaud, 1999; Kimura et al. 2004). In this work, this dye was used as an indirect marker of cellular carotenoid content.

\section{MATERIALS AND METHODS}

\section{Algae and growth conditions}

Nine strains of Dunaliella salina from different geographic origins were used in our study (Table 1). Two of the strains were obtained from culture collections: CCAP Culture Collection, UK and National Bank of Algae, Spain. One mutant derived from CCAP 19/30 was generated by chemical mutagenesis with EMS (see below). The remaining strains were isolated from solar saltworks

*Corresponding author 
Table 1. Dunaliella salina strains.

\begin{tabular}{|c|c|c|}
\hline Strain & Origin & Isolation year \\
\hline CCAP 19/30 & North Sinai, Israel (CCAP collection) & 1976 \\
\hline CCMAR-71 & CCAP $19 / 30$ mutant $^{a}$ & 2003 \\
\hline BCA 421 & Tenefe $^{b}$ & 1992 \\
\hline ITC-501 & Vargas $^{b}$ & 2005 \\
\hline ITC-502 & Punta $^{\mathrm{b}}$ & 2005 \\
\hline ITC-503 & Tenefe $^{b}$ & 2005 \\
\hline ITC-504 & Rio $^{c}$ & 2005 \\
\hline ITC-607 & Guatiza $^{c}$ & 2006 \\
\hline ITC-506 & Majo $^{d}$ & 2003 \\
\hline
\end{tabular}

${ }^{a}$ Mutant obtained by ethyl methane sulphonate mutagenesis (present work).

${ }^{b}$ Isolated from solar saltwork in Gran Canaria, Spain. ITC culture collection, Gran Canaria, Spain.

${ }^{c}$ Isolated from solar saltwork in Lanzarote, Spain. ITC culture collection, Gran Canaria, Spain.

${ }^{d}$ Isolated from solar saltwork in Fuerteventura, Spain. ITC culture collection, Gran Canaria, Spain.

located at the Canary Islands following the agar plating technique and deposited at the culture collection of the Canary Islands Technological Institute.

All strains were cultivated in the medium described by Semenenko and Abdullaev (1980) containing $1 \mathrm{M} \mathrm{NaCl}$, except during the mutagenesis procedure which is described below. Cultures were bubbled with $3 \% \mathrm{CO}_{2}$ in air $(\mathrm{v} / \mathrm{v})$, at continuous light $\left(200 \mu \mathrm{mol}\right.$ photon $/ \mathrm{m}^{2} /$ second $)$ and grown in $500 \mathrm{~mL}$ borosilicate flasks containing $500 \mathrm{~mL}$ of media at $25 \pm 2^{\circ} \mathrm{C}$. The stock was maintained by subculturing every week. In all cases the stock culture was used as inoculum. The cultures were harvested at the beginning of the stationary growth phase by centrifugation $(5000 \mathrm{~g})$.

\section{Cell growth and pigment analysis}

Cell number was counted daily in a Thoma haemocytometer. Maximum cell density was that one achieved at the beginning of the stationary growth phase for each strain and it is expressed as cells $/ \mathrm{mL}$. Growth rate was calculated according to Crow and Kimura (1970) and expressed as divisions per day (div./day).

Chlorophyll and carotenoid content were extracted from algal pellets with cold methanol and assayed according to Wellburn (1994). As $\beta$-carotene is the main carotenoid in the pigment composition of $D$. salina (Jiménez and Pick,
1994), total carotenid content is a good indicator of the $\beta$ carotene content in this alga.

The carotenoid productivity ( $\mu \mathrm{g} / \mathrm{mL} /$ day) was calculated from the concentration of carotenoids at the beginning of stationary growth phase and the total time of culture.

\section{Ethyl methane sulphonate (EMS) mutagenesis and manual mutant screening}

Dunaliella salina CCAP 19/30 cells were cultured up to mid-exponential phase in Walne medium adjusted to $1.5 \mathrm{M}$ $\mathrm{NaCl}$ (Orset and Young, 1999). A modified procedure as described by Tripathi et al. (2001) was used. In short, $5 \mathrm{~mL}$ culture samples were centrifuged for $5 \mathrm{~min}$ at $1250 \mathrm{~g}$ and suspended in $500 \mu \mathrm{L}$ of PN buffer $(0.1 \mathrm{M}$ sodium phosphate $\mathrm{pH} 7,0 ; 1.5 \mathrm{M} \mathrm{NaCl})$. Cells were exposed to concentrations between 0.12 and $1.68 \%(\mathrm{w} / \mathrm{v})$ of EMS. To ensure proper exposure to the alkylating agent, samples were vortexed vigorously and incubated at room temperature for $1 \mathrm{~h}$ in the dark. The latter precaution is needed to decrease the activity of photo-inducible DNA repair mechanisms. EMS was inactivated by $500 \mu \mathrm{L}$ of fresh-made sterile $10 \%(\mathrm{w} / \mathrm{v})$ sodium thiosulphate. The cells were washed with $1 \mathrm{~mL}$ of PN buffer, collected by centrifugation (5 min at $1250 \mathrm{~g}$ ), re-suspended in $1 \mathrm{~mL}$ of Walne medium with $9 \% \mathrm{NaCl}$ and kept in the dark for 24 hrs. Mortality was estimated microscopically by counting motile cells. Cells treated with $1.44 \%$ (w/v) EMS were 
further used, as this concentration gave rise to an apparent mortality of $90 \%$. Mutant manual screening was carried out in 96-well microtiter plates upon serial dilution down to 1 cell per well. In order to enrich the surviving population for carotenoid-overproducing mutants, cells were grown in the presence of $20 \mu \mathrm{M}$ diphenylamine (DPA), a known carotenoid synthesis inhibitor (Chen et al. 2003). The mutant phenotype was scored visually by the intensity of the reddish colour of clonal cultures growing in individual wells in the presence and absence of DPA.

\section{Flow cytometric analysis}

Intrinsic structural parameters measured by flow cytometry such as forward scatter (FSC; related to cell size), side scatter (SSC; related to cell shape) and FL4 (red fluorescence, $675 \mathrm{~nm}$; related to fluorescence of chlorophyll) were those based on autofluorescence of control cells.

Lipid content was determined as an extrinsic parameter following a modified protocol of de la Jara et al. (2003) as follows. An aliquot of cell sample $\left(1 \mathrm{~mL}\right.$ at $10^{5}-10^{6}$ cell $/ \mathrm{mL}$ ) was treated with $12.5 \mu \mathrm{L}$ of a working solution of NR (Sigma Inc.) and acetone $(0,1 \mathrm{mg} / \mathrm{mL})$. This mix was gently vortexed and incubated for $10 \mathrm{~min}$ at $37^{\circ} \mathrm{C}$ in darkness. NR fluorescence was collected depending on the polarity of the intracellular environment. Specifically, the FL2 channels (yellow fluorescence, $\lambda=575 \mathrm{~nm}$ ) were used to estimate lipids.

All cytometric measurements were done using an Epics XL flow cytometer (Beckman Coulter Instruments) equipped with a $488 \mathrm{~nm}$ argon laser. Calibration of the equipment was made every day using Flow-Check ${ }^{\mathrm{TM}}$ fluorospheres (Beckman Coulter). Approximately 3000 cells were analysed using a log amplification of the fluorescent signal and the FSC, SSC, FL2 and FL4 values, referred throughout the text are mean of the chosen subpopulations in each analyzed samples. Non-stained cells were used as an autofluorescence control. Measurements were done every $24 \mathrm{hrs}$ and the mean value was estimated for each strain in all period of exponential growth. Data were expressed as fluorescence arbitrary units.

\section{Statistical analysis}

Three culture of each strain were analyzed in all experimental conditions. Data were tested for statistical significance using linear and logarithmic regression analysis. Statistically significant differences for growth and carotene for the different strains were established by a non parametrical test, the Kruskal-Wallis test. In all cases the alpha level used was 0.05 .

\section{RESULTS}

Observation through the light microscope suggested a high degree of size variability and some plasticity among the strains. This observation was corroborated by the cytometric parameters FSC and SSC (Figure 1).

As for the other cytometric parameters assessed, a significant increase in the FL2 signal of cells stained with NR was detected, which corresponds to the intracellular intake of the dye (Figure 2). The FL2 signal correlated significantly with the cellular content of carotenoid estimated every 24 hrs during the growth of the different $D$. salina strains (Figure 3). The relationship between the $\mathrm{Chl} / \mathrm{Car}$ and the cytometric signals combined as (FL4) $\mathrm{x}$ $(\text { FL2) })^{-1}$ was also significant (Figure 4).

Maximum cell densities and growth rate reached by the strains are shown in the Table 2. The statistical analysis of this parameter showed that significant differences exist among the evaluated strains. The strain reaching the highest cellular density was CCAP 19/30, while the strain attaining the lowest cellular density was ITC-503. The mean value for the rest of the strains was $82.57 \pm(22.90) \cdot 10^{5}$ cell $/ \mathrm{mL}$. Concerning pigments, the set of strains analysed showed significant differences in the mean $\mathrm{Chl} / \mathrm{Car}$ ratios (Table 2).

Growth rate correlated significantly in all the strains with size and cellular complexity assessed as FSC.SSC. The larger and more complex strains showed the lowest growth rate. This trend was observed when correlating growth rate and $\mathrm{Chl} / \mathrm{Car}$ assessed cytometrically from chlorophyll autofluorescence and the signal of NR stained cells. Higher growth rates were reached by strains with the lowest Chl/Car (Figure 5).

We found a significant correlation between carotene productivity and growth rate, the strains with the higher growth rates reached the higher carotene productivities (Figure 6), while the correlation founded between carotenoid productivity and the cellular content of carotenoids was not significant. This allowed us to identify the cellular growth rate as a factor more decisive than carotene content per cell in the differences carotene production observed between all strains.

Assuming growth rate as a good indicator of the carotene productivity, we composed the formula (FL2 $\mathrm{FL}^{-1}$ ) $\mathrm{x}$ $(\mathrm{FSC} \times \mathrm{SSC})^{-1}$ which integrates the cellular parameters assessed by flow cytometry which kept a significant correlation with the growth rates and includes them either in the numerator or in the denominator depending on the sing of correlation. Thus, those parameters integrated in the numerator, which correspond to the pigment composition of the strains, were found to be associated to the higher growth rates according to our results, while morphological parameters were associated to the strains with lower growth rates. The analysis of the correlation between the carotene productivity and the data from this formula gave a significant correlation (Figure 7) and confirmed its suitability to assess the potential carotene productivity of strains of Dunaliella salina. Comparing our strains, the strain CCAP 19/30 reached the higher carotene productivity 
Table 2. Dunaliella salina strains (data of three culture replicates $\pm s d$ ).

\begin{tabular}{|c|c|c|c|c|}
\hline Strains & $\begin{array}{c}\text { Cell maximum } \\
\text { density } \\
(\mathbf{c e l} . / \mathbf{m l} \cdot \mathbf{1 0})\end{array}$ & $\begin{array}{c}\text { Growth rate } \\
(\mathbf{d i v} . / \mathrm{day})\end{array}$ & Chlorophyll/Carotene & $\begin{array}{c}\text { Carotene } \\
\mathbf{( \mu g / m I})\end{array}$ \\
\hline CCAP 19/30 & $245.97( \pm 92.70)$ & $0.77( \pm 0.04)$ & $3.50( \pm 0.46)$ & $11.97( \pm 3.01)$ \\
\hline CCMAR-71 & $91.46( \pm 17.00)$ & $0.56( \pm 0.02)$ & $3.83( \pm 1.13)$ & $11.43( \pm 1.61)$ \\
\hline BCA 421 & $103.54( \pm 5.60)$ & $0.63( \pm 0.03)$ & $4.42( \pm 1.01)$ & $10.57( \pm 3.20)$ \\
\hline ITC-501 & $67.71( \pm 6.15)$ & $0.49( \pm 0.07)$ & $5.45( \pm 1.36)$ & $8.41( \pm 4.11)$ \\
\hline ITC-502 & $79.58( \pm 27.68)$ & $0.54( \pm 0.05)$ & $5.45( \pm 0.87)$ & $5.83( \pm 0.28)$ \\
\hline ITC-503 & $25.97( \pm 5.69)$ & $0.40( \pm 0.11)$ & $9.96( \pm 0.42)$ & $5.47( \pm 0.75)$ \\
\hline ITC-504 & $92.79( \pm 18.81)$ & $0.49( \pm 0.01)$ & $7.64( \pm 0.45)$ & $3.23( \pm 0.88)$ \\
\hline ITC-607 & $97.30( \pm 9.09)$ & $0.42( \pm 0.05)$ & $6.06( \pm 0.68)$ & $7.48( \pm 1.36)$ \\
\hline ITC-506 & $45.59( \pm 19.78)$ & $0.46( \pm 0.03)$ & $6.22( \pm 2.29)$ & $8.08( \pm 3.83)$ \\
\hline
\end{tabular}

and was followed by BCA 421 and the mutant CCMAR-71 (Figure 8).

\section{DISCUSSION}

The search of target parameters suitable to differentiate among different strains was the first step in the present attempt to set up the characterization of $D$. salina strains by flow cytometry. Carotenoid cell content turned out to be the most versatile among all the variables analyzed. Pigment composition is an important factor in the physiological behaviour and productivity of $D$. salina since the photosynthetic efficiency of this alga increases due to the high $\beta$-carotene content under high light conditions. A high ratio between the photoprotective pigment ( $\beta$-carotene) and the photosynthetic active pigment induces an increase in the maximum photosynthesis per unit of chlorophyll and photosaturation level of the cells in conditions of massive cultures, associated with the photoprotective properties of $\beta$-carotene (Melis et al. 1998). Furthermore, the variation in the $\mathrm{Chl} / \mathrm{Car}$ is the usual strategy of photoadaptation for most of the species of microalgae and especially relevant in D. salina. Although a high $\mathrm{Chl} / \mathrm{Car}$ ratio is linked to higher photosynthetic efficiencies in low irradiation conditions, photon flux density increases produces a drop of the photosynthetic efficiency and cells respond by diminishing photosynthetic antenna size and synthesizing photoprotection pigments (MacIntyre et al. 2002). Thus, the potential photodamage is minimized while an efficient use of incident photons in photosynthesis at high irradiance occurs (Hagen et al. 2000; Raven and Geider, 2003). Those strains with lowest $\mathrm{Chl} / \mathrm{Car}$ ratio would show photosynthetic levels capable of reaching higher cellular growth rates (Guevara et al. 2005) and maximum cell densities, making up a potential indicator of the growth capacity of the cultures which could be used to select strains.

Since flow cytometry is a fluorescence-based technique, it was necessary to overcome the low fluorescence of carotenoids. This issue was solved by staining cells with the lipophilic dye Nile Red and, as far as we know, this is the first time that NR is used to assess carotenoid cellular content in D. salina. Previous works showed the possibility of using this dye as an indicator of the lipidic and fatty acid composition in some species using flow cytometry (de la Jara et al. 2003). In D. salina and in other alga, as Haematococcus sp, both the fatty acid profile and lipid composition are closely related to the massive carotenoids accumulation (Rabbani et al. 1998; Grünewald et al. 2001; Zhekisheva et al. 2005) in such a way that it is possible to establish a link between them (Mendoza et al. 1999). Our results show that changes in the $D$. salina lipidic composition associated with the carotenogenetic process could be detected by flow cytometry using NR, a lipidic fluorescent marker that enabled us to estimate the carotene cellular content despite the low fluorescence of carotenoids.

This technique had previously been used in the isolation and characterization of carotenoid hyperproducing mutants of yeast (Gil-Hwan et al. 1991), but this work only assessed the carotene cellular contents as a target variable. However, carotenoid productivity from $D$. salina is fundamentally determined by other parameters, such as cellular division 
rate and biomass production (Hejazi and Wijffels, 2003). This approach to the potential productivity of the strains we propose is more comprehensive than the simple evaluation of carotenoid cellular contents because as well as this variable, we include other parameters such as chlorophyll/carotenoid ratio, cellular size and complexity, which are related with growth rate in D. salina (Gómez et al. 1999; Giordano, 2001; Gómez and González, 2001). With this new approach to select carotenoid hyperproducing strains of $D$. salina it is possible to directly estimate the potential growth rates and carotene productivity in complex samples with different strains. Thus, we found that the highest productivity corresponded to D. salina CCAP $19 / 30$ and to its mutant, BCA 421, as well as to CCMAR-71. These strains reached the highest values for the selective cytometric parameters as well. In subsequent works we have evaluated others wild and mutant strains, proving the viability of the flow cytometry techniques in the estimations of carotene content and selection of $D$. salina hyperproducing strains (data not shown).

Besides flow cytometry shows clear advantages compared with traditional techniques. One of the most interesting ones is, for instance, the possibility of processing a high number of samples. This is a key factor to succeed in the screening process. Moreover, cell sorters linked to flow cytometers would not only allow the characterization of strains but also its automated isolation (Gil-Hwan et al. 1991). Thus, flow cytometry techniques would speed up mutant selection which, otherwise, become slow and labour intensive procedures. The possibility of linking flow cytometry with molecular techniques already used to characterize strains of $D$. salina (Raja et al. 2007) is also very promising and some works, such as the cytometric characterization of mRNA expression in human cells, done by Abe and Kool (2006), focus on this issue. However, further research is necessary on fluorescent genetic expression markers, suitable for flow cytometry, associated with carotenogenesis at the RNA and cellular level.

So far only a few genetic characterization studies about intraspecific variation in $D$. salina have been published. González et al. (1998) showed a low intraspecific genetic variability in strains from different countries. However, an important correspondence among intraspecific genetic variability and morphological and physiological behaviour has been found in D. salina, though the morphologic traditional criteria of taxonomical classification present diverse limitations (Cifuentes et al. 2001; Gómez and González, 2001; González et al. 2001). In the present work, it can be underlined the wide morphological and physiological variation found among native strains isolated from various saltworks in close geographical vicinity. Six out of nine strains used in this study were isolated from Canaries saltworks, some of these locations are $10 \mathrm{Km}$ from each other. The current underexploitation of saltworks and the low avifauna density in the Canary Islands, main vector of plankton dispersion in isolated wetlands (Green et al. 2005), might favour the intraspecific differentiation due to isolation.

Summarizing, the possibility of using NR as an effective dye to indirectly assess the carotene cellular content in $D$. salina composing different cytometric parameters into a formula to select potential carotenoid hyperproducing strains has been shown. This finding favours the development of high-throughput screening techniques for $\beta$-carotene hyperproductive strains of $D$. salina, saving time and staff in trials and thus minimizing production costs.

\section{REFERENCES}

ABE, Hiroshi and KOOLL, Eric T. Flow cytometric detection of specific RHAs in native human cells with quenched autoligating FRET probes. Proceedings of the National Academy of Sciences of the United States of America, January 2006, vol. 103, no. 2, p. 263-268.

ALONZO, F. and MAYZAUD, P. Spectrofluorometric quantification of neutral and polar lipids in zooplankton using Nile red. Marine Chemistry, November 1999, vol. 67, no. 3-4, p. 289-301.

BEN-AMOTZ, Ami. Industrial production of microalgae cell-mass and secondary products - major industrial species Dunaliella. In: RICHMON, Amos ed. Handbook of microalgal culture. Oxford, Blakwell, 2004, p. 273-280.

CHEN, Young; LI, Defa F.; LU, Wenqing Q.; XING, Jianjun J.; HUI Bodi D. and HAN, Yashan S. Screening and characterization of astaxanthin-hyperproducing mutants of Haematococcus pluvialis. Biotechnology Letters, April 2003 , vol. 25 , no. 7 , p. 527-529.

CIFUENTES, Ana S.; GONZÁLEZ, Mariela A.; INOSTROZA, Ingrid and AGUILERA, Alejandra. Reappraisal of physiological attributes of nine strains of Dunaliella (Chlorophyceae): growth and pigment content across a salinity gradient. Journal of Phycology, April 2001, vol. 37, no. 2, p. 334-344.

CROW, James F. and KIMURA, Motoo. An introduction to population genetics theory. New York, Harper and Row, 1970. 591 p. ISBN 0-808-72901-2.

DE LA JARA, Adelina; MENDOZA, Héctor; MARTEL, Antera; MOLINA, Cristina; NORDSTRÖN, Laurette; DE LA ROSA, Vladimir and DÍAZ, Ricardo. Flow cytometric determination of lipid content in marine dinoflagellate, Crypthecodinium cohnii. Journal of Applied Phycology, September 2003, vol. 15, no. 5, p. 433-438.

GARCÍA-GONZÁLEZ, M.; MORENO, J.; CAÑAVATE, J.P.; ANGUIS, V.; PRIETO, A.; MANZANO, C.; FLORENCIO, F.J. and GUERRERO, M.G. Conditions for opoen-air outdoor culture of Dunaliella salina in southern Spain. Journal of Applied Phycology, March 2003, vol. 15, no. 2-3, p. 177-184. 
GARCÍA-GONZÁLEZ, M.; MORENO, J.; MANZANO, J.C.; FLORENCIO, F.J. and GUERRERO, M.G. Production of Dunaliella salina biomass rich in 9-cis- $\beta$ carotene and lutein in closed tubular photobiorreactor. Journal of Biotechnology, January 2005, vol. 115, no. 1, p. 81-90.

GIL-HWAN, An; BIELICH, Jane; AUERBACH, Robert and JOHNSON, Eric A. Isolation and characterization of carotenoid hyperproducing mutants of yeast by flow cytometry and cell sorting. Nature Biotechnology, January 1991, vol. 9, p. 70-73.

GIORDANO, Mario. Interaction between $\mathrm{C}$ and $\mathrm{N}$ metabolism in Dunaliella salina cells cultured at elevated $\mathrm{CO}_{2}$ and high $\mathrm{N}$ concentrations. Journal of Plant Physiology, May 2001, vol. 158, no. 5, p. 577-581.

GÓMEZ, Patricia I.; GONZÁLEZ, Mariela A. and BECERRA José. Quantity and quality of $\beta$-carotene produced by two strain of Duanliella salina (Teodoresco 1905) from the north of Chile. Boletín de la Sociedad Chilena de Química, December 1999, vol. 44, no. 4, p. 463468.

GÓMEZ, Patricia I. and GONZÁLEZ, Mariela A. Genetic polymorphism in eight Chilean strains of the carotenogenic microalga Dunaliella salina Teodoresco (Chlorphyta). Biological Research, 2001, vol. 34, no. 1, p. 23-30.

GONZÁLEZ, Mariela A.; GÓMEZ, Patricia I. and MONTOYA, Rolando. Comparison of PCR-RFLP analysis of the ITS region with morphological criteria of various strains of Dunaliella. Journal of Applied Phycology, December 1998, vol. 10, no. 6, p. 573-580.

GONZÁLEZ, Mariela A.; COLEMAN Anette W.; GÓMEZ, Patrica I. and MONTOYA, Rolando. Phylogenetic relationship among various strains of Dunaliella (Chlorophyceae) based on nuclear ITC rDNA sequences. Journal of Phycology, August 2001, vol. 37, no. 4, p. 604-611.

GREEN, Andy J.; SÁNCHEZ, Marta I.; AMAT, Francisco; FIGUEROLA, Jordi; HONTORIA, Francisco; RUIZ, Olga and HORTAS, Francisco. Dispersal of invasive and native shrimps Artemia (Anostraca) via waterbirds. Limnology and Oceanography, March 2005, no. 50, vol. 2, p. 737-742.

GRÜNEWALD, Kay; HIRSCHEBERG, Joseph and HAGEN, Christoph. Ketocarotenoid biosynthesis outside of plastids in the unicellular green alga Haematococcus pluvialis. Journal of Biological Chemistry, February 2001, vol. 276, no. 8, p. 6023-6029.

GUEVARA, Miguel; LODEIROS, César; GÓMEZ, Olga; LEMUS, Nathalie; NÚÑEZ, Paulino; ROMERO, Lolymar; VÁSQUEZ, Aléikar and ROSALES, Néstor. Carotenogénesis de cinco cepas del alga Dunaliella sp. (Chlorophyceae) aisladas de lagunas hipersalinas de
Venezuela. Revista de Biología Tropical, December 2005, vol. 53, no. 5-4, p. 331-337.

HAGEN, Christoph; GRÜNEWALD, Kay; SCHMIDT, Silvio and MULLER, Jens. Accumulation of secondary carotenoids in flagellates of Haematococcus pluvialis (Chlorophyta) is accompanied by an increase in per unit chlorophyll productivity of photosynthesis. European Journal of Phycology, February 2000, vol. 35, no. 1, p. 7582.

HEJAZI, M.A. and WIJFFELS, R.H. Effect of light intensity on $\beta$-carotene production and extraction by Dunaliella salina in two-phase bioreactors. Biomolecular Engineering, July 2003, vol. 20, no. 4-6, p. 171-175.

JIMÉNEZ, Carlos and PICK, Uri. Differential stereoisomer of $\beta, \beta$-carotene in thylakoids and in pigment globules in Dunaliella. Journal of Plant Physiology, 1994, vol. 143, p. 257-263.

KIMURA, K.; YAMAOKA, M. and KAMISAKA, Y. Rapid estimation of lipids in oleaginous fungi and yeasts using Nile red fluorescence. Journal of Microbiological Methods, March 2004, vol. 56, no. 3, p. 331-338.

LEÓN, Rosa; MARTÍN, Marta; VIGARA, Javier; VÍLCHEZ, Carlos and VEGA, José María. Microalgae mediated photoproduction of $\beta$-carotene in aqueous-organic two phase systems. Biomolecular Engineering, July 2003, vol. 20, no. 4-6, p. 177-182.

MACINTYRE, Hugh L.; KANA, Todd; ANNING, Tracy and GEIDER, Richard J. Photoacclimation of photosynthesis irradiance response curves and photosynthetic pigments in microalgae and cyanobacteria. Jounal of Phycology, February 2002, vol. 38, no. 1, p. 1738.

MELIS, Anastasios; NEIDHARDT, John and BENEMANN John R. Dunaliella salina (Chlorophyta) with small chlorophyll antenna sizes exhibit higher photosynthetic productivities and photo use efficiencies than normally pigmented cells. Journal of Applied Phycology, December 1998, vol. 10, no. 6, p. 515-525.

MENDOZA, Héctor; MARTEL, Antera; JIMÉNEZ DEL RÍO, Miguel and GARCÍA-REINA, Guillermo. Oleic acid is the main fatty acid related with carotenogenesis in Dunaliella salina. Journal of Applied Phycology, February 1999, vol. 11, no. 1, p. 15-19.

OREN, Aharon. A hundred years of Dunaliella research: 1905-2005. Saline Systems [online]. 4 July 2005, vol. 1, no. 2 [cited 1 June 2007]. Available from Internet: http://www.salinesystems.org/content/1/1/2.

ORSET, Sandra and YOUNG, Andrew J. Low temperatureinduced synthesis of $\alpha$-carotene in the microalga Dunaliella 
salina (Chlorophyta). Journal of Phycology, June 1999, vol. 35 , no. 3 , p. 520-527.

PHADWAL, K. and SINGH, P.K. Isolation and characterization of an indigenous isolate of Dunaliella $\mathrm{sp}$ for $\beta$-carotene and glycerol production from hypersaline lake in India. Journal of Basic Microbiology, September 2003, vol. 43, no. 5, p. 423-429.

PULZ, Otto. Photobiorreactors: production systems for phototrophic microorganisms. Applied Microbiology and Biotechnology, October 2001, vol. 57, no. 3, p. 287-293.

RABBANI, Said; BEYER, Peter; LINTHING, Johanes V.; HUGUENEY, Philippe and KLEINING, Hans. Induced $\beta$ carotene synthesis driven by triacylglycerol deposition in the unicellular alga Dunaliella bardawil. Plant Physiololgy, April 1998, vol. 116, no. 4, p. 1239-1248.

RAJA, R; HEIMAISWARYA, R. and RENGASAMY, R. Exploitation of Dunaliella for $\beta$-carotene production. Applied Microbiology and Biotechnology, March 2007, vol. 74, no. 3, p. 517-523.

RAVEN, John A. and GEIDER, Richard J. Adaptation, acclimation and regulation in algal photosynthesis. In: LARKUM, Anthony W.; DOUGLAS, Susan E. and RAVEN, John A. eds. Photosynthesis in Algae. Dordrecht, Kluwer Academic Publisher, 2003, p. 385-412.

SEMENENKO, V.E. and ABDULLAEV, A.A. Parametric control of $\beta$-carotene biosynthesis in Dunaliella salina cells under conditions of intensive cultivation. Soviet Plant Physiology, 1980, vol. 27, no. 1, p. 22-30.

SHAISH, Aviv; BEN-AMOTZ, Ami and AVRON, Mordhay. Production and selection of high $\beta$-carotene mutants of Dunaliella bardawil (Chlorophyta). Journal of Phycology, October 1991, vol. 27, no. 5, p. 652-656.

TRIPATHI, U.; VENKATESHWARAN, G.; SARADA, R. and RAVISHANKER, G.A. Studies on Haematococcus pluvialis for improved production of astaxanthin by mutagenesis. World Journal Microbiology and Biotechnology, March 2001, vol. 17, no. 2, p. 143-148.

WELLBURN, Alan R. The spectral determination of chlorophylls a and $\mathrm{b}$, as well as total carotenoids, using various solvents with spectrophotometers of different resolution. Journal of Plant Physiology, January 1994, vol. 144, p. 307-313.

ZHEKISHEVA, Mirash; ZARKA, Aliza; KHOZINGOLDBERG, Inna; COHEN, Zvi and BOUSSIBA, Sammy. Inhibition of astaxanthin synthesis under high irradiance does not abolish triacyglycerol accumulation in the green alga Haemaotococcus pluvialis. Journal of Phycology, August 2005, vol. 41, no. 4, p. 819-826. 


\section{APPENDIX}

\section{FIGURES}

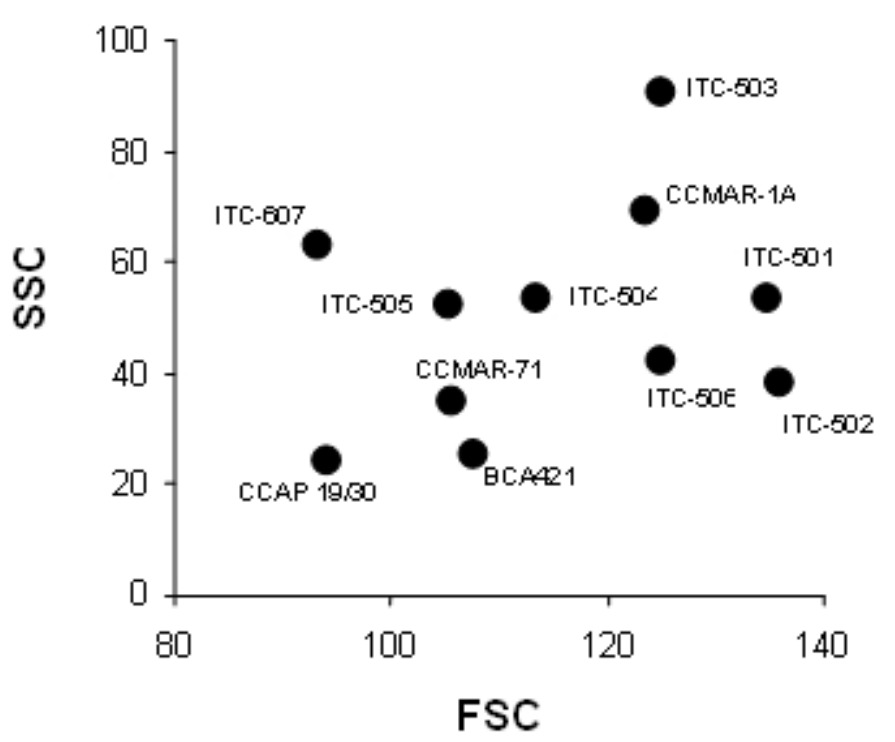

Figure 1. Mean cellular size (FSC) vs. mean cellular complexity (SSC) of different strains of Dunaliella salina assessed by flow cytometry (data expressed as arbitrary units). Each dot represents one subpopulation of $D$. salina.

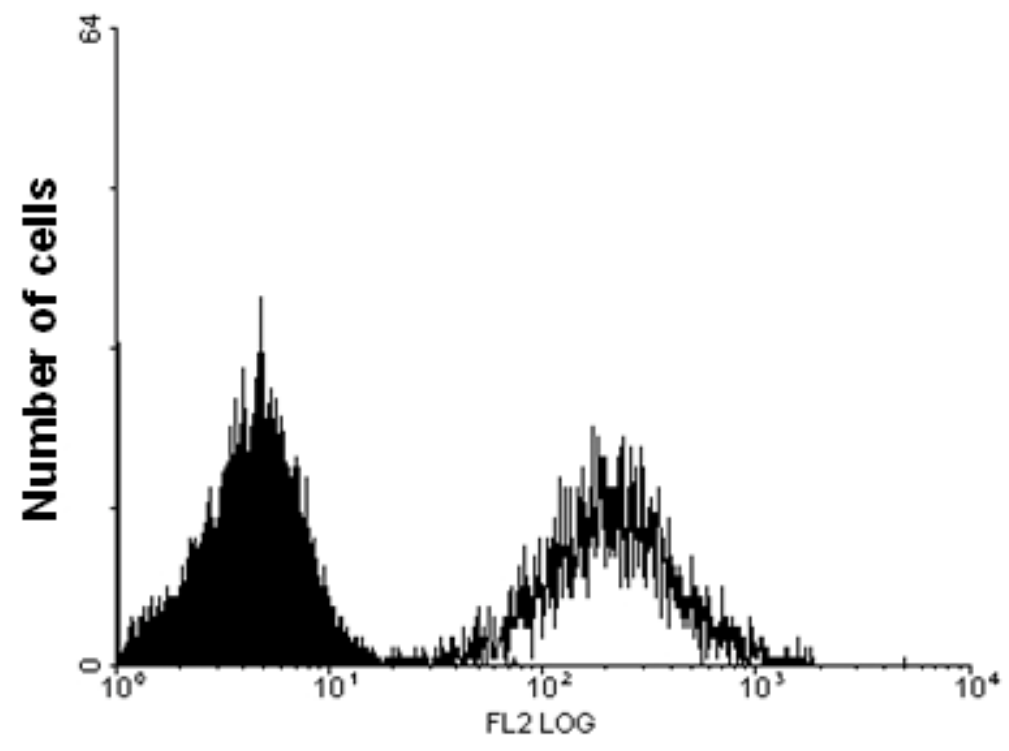

Figure 2. Variation of cytometric signal (FL2: yellow fluorescence, $\lambda=575 \mathrm{~nm}$ ) in cell stained with NR (D. salina, BCA 421). A similar behaviour was observed in all the strains and the mean value of FL2 was assumed as reference value. 


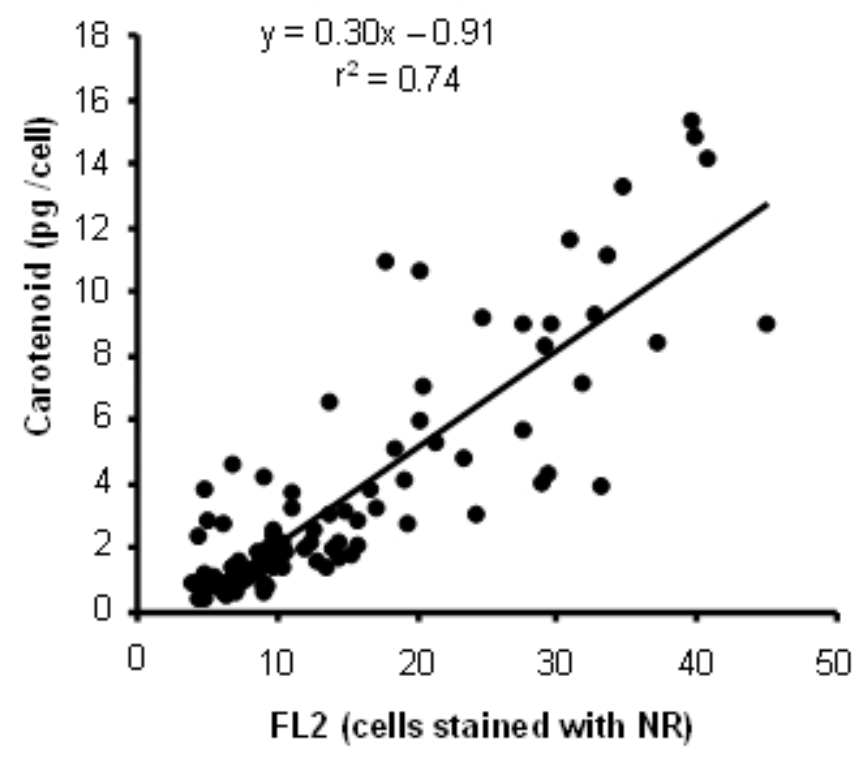

Figure 3. Correlation between carotene cellular content and cytometric FL2 signal of cells stained with NR (cytometry data expressed as arbitrary fluorescence units). The pigment composition and cytometric FL2 signal were estimated in each strain and culture replicate every $24 \mathrm{hrs}$. The correlation detected was significant $(p<0.01)$.

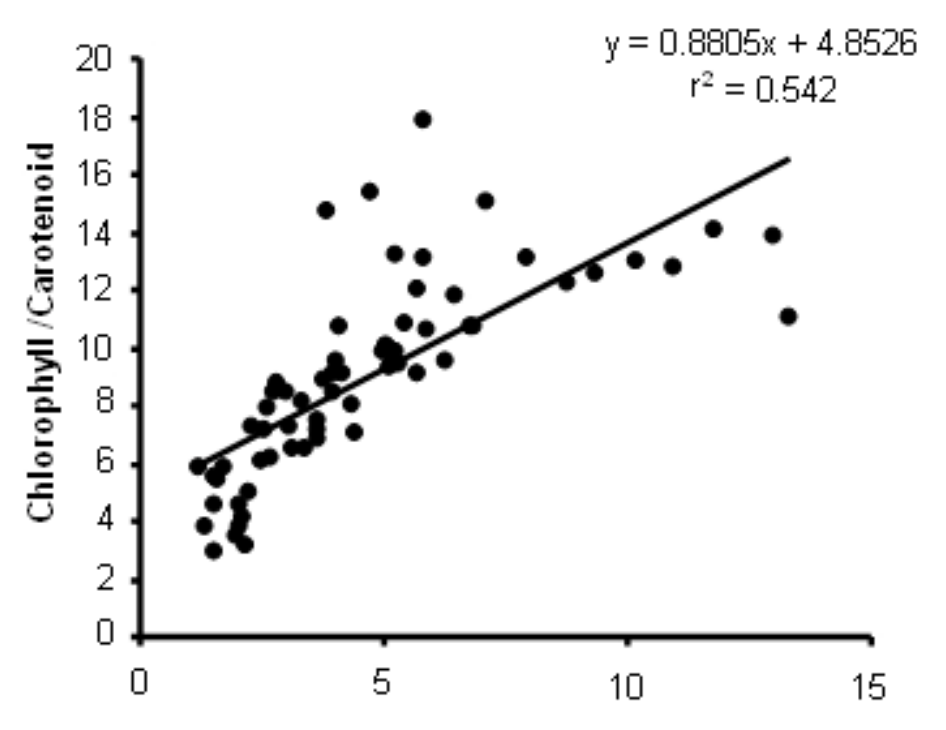

$\mathrm{FL4} \cdot \mathrm{FL}^{-1}$ (Cells stained with NR)

Figure 4. Correlation between the carotene to chlorophyll ratio and FL4 FL2 ${ }^{-1}$ ratio of cells stained with NR (cytometry data expressed as arbitrary fluorescence units). The pigment composition and cytometric FL2 signal were estimated in each strain and culture replicate every $24 \mathrm{hrs}$. The correlation detected was significant $(p<0.01)$. 

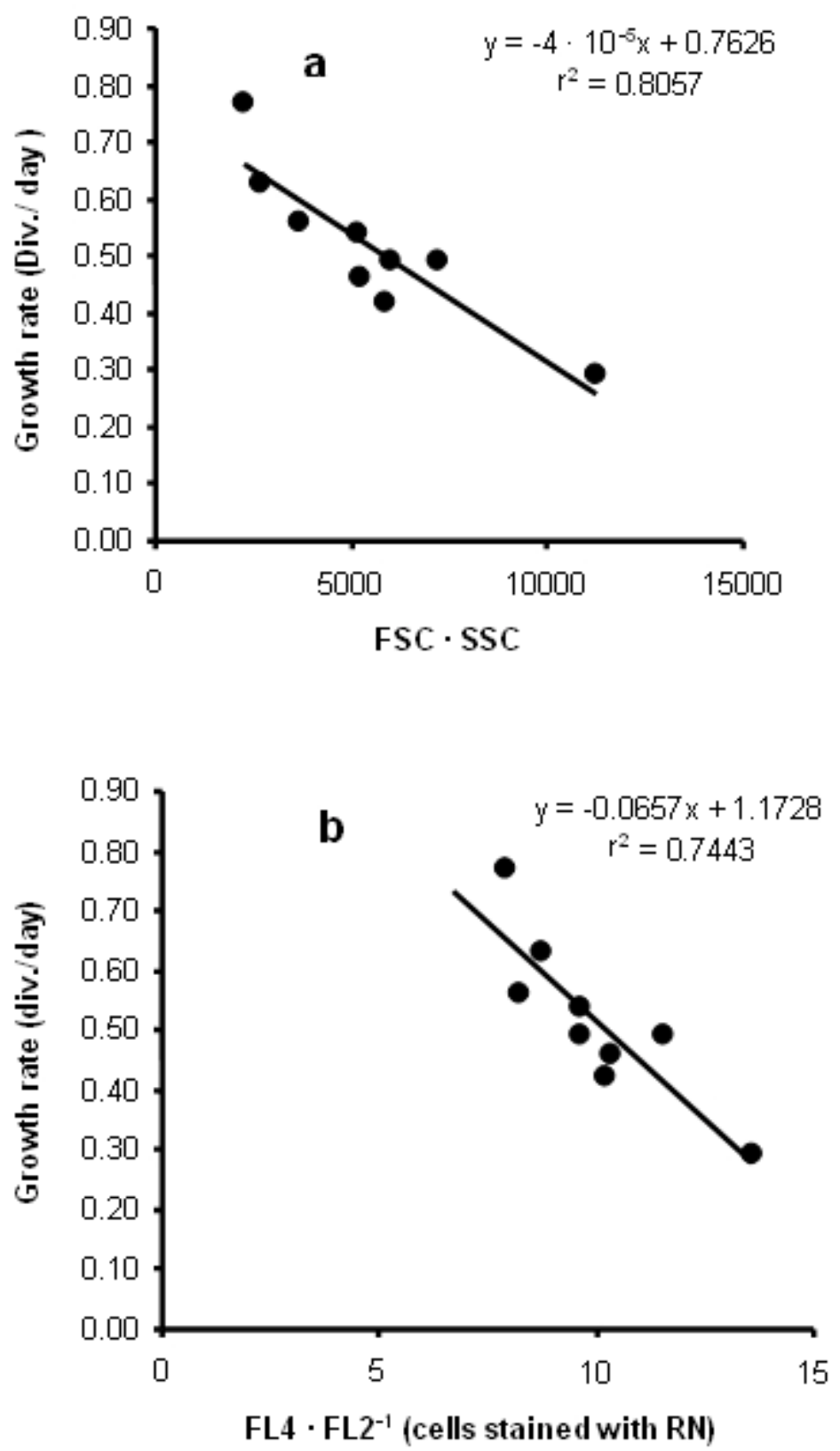

Figure 5. Correlation between the cellular growth rate with size and complexity combined as (FSC SSC) (a) and with the chlorophyll/carotene ratio in NR stained cells assessed by flow cytometry (FL4 FL2 ${ }^{-1}$ ). (b). The represented data correspond to the average value reached by each strain in the exponential growth phase. The correlation detected was significant $(p<0.01)$. 
Mendoza, H. et al.

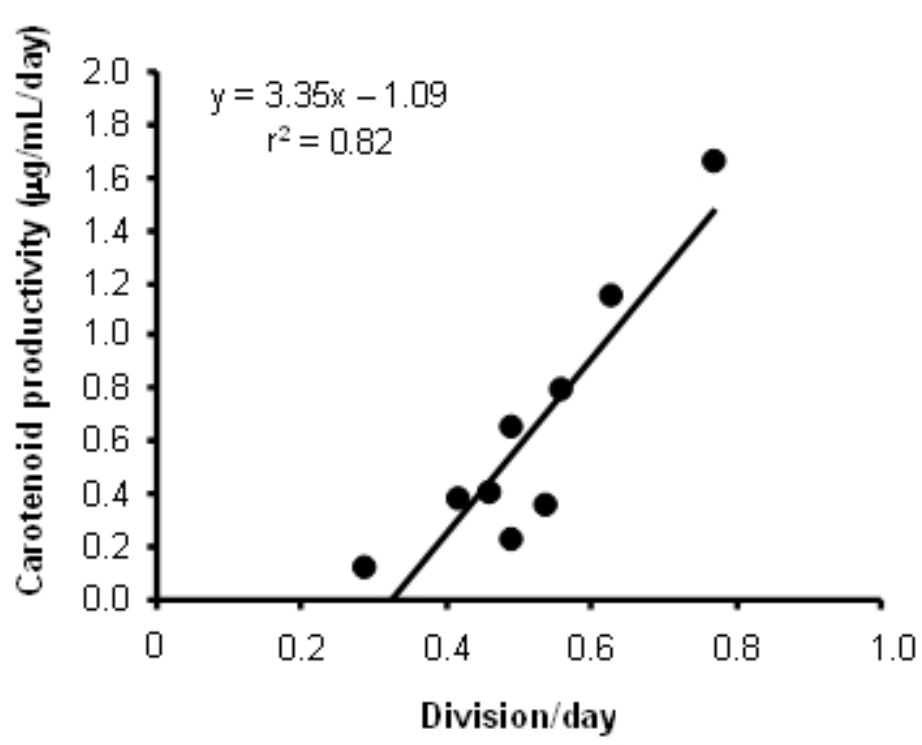

Figure 6. A significant correlation between cellular growth rate of each strain and carotene productivity was found ( $p<0.01)$.

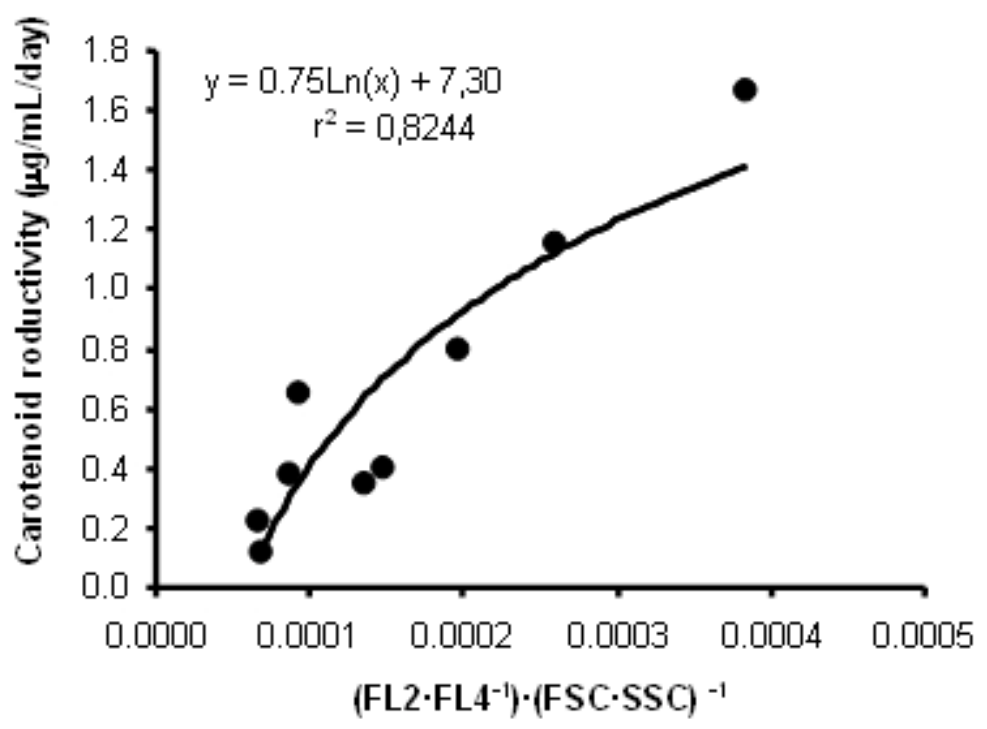

Figure 7. Correlation between the different cytometric variables combined as (FL2 FL4 ${ }^{-1}$ ) (FSC SSC) ${ }^{-1}$ with carotene productivity. The correlation detected was significant $(p<0.01)$. 


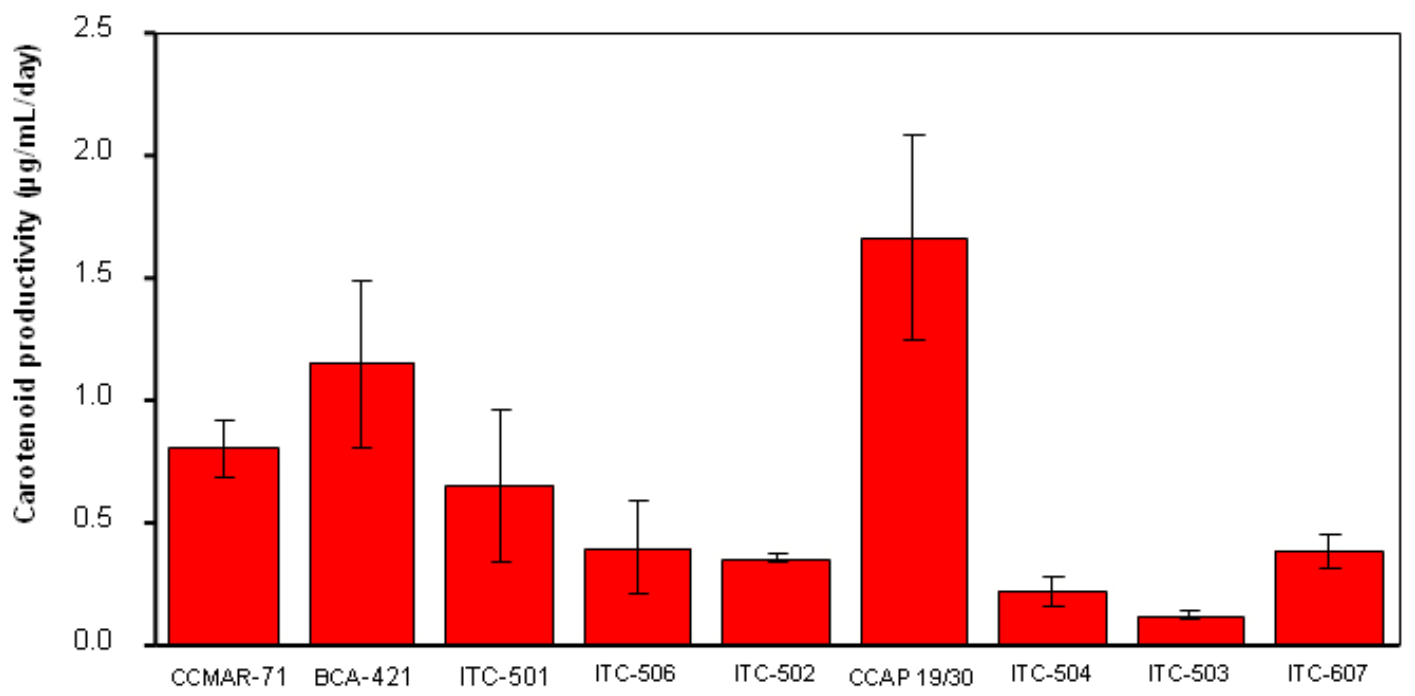

Figure 8. Carotenoid productivity ( $\mu \mathrm{g} / \mathrm{mL} / \mathrm{day}$ ) of different Dunaliella salina strains (data are mean of three replicates). 